\title{
SILYMARIN: ADJUNCTIVE TREATMENT IN HEPATITIS C ASSOCIATED ORAL LICHEN PLANUS
}

\author{
Malak Yousef Mohamed Shoukheba* and Shereen Abdel Moula Ali*
}

\begin{abstract}
Recently, lichen planus has been reported to occur with chronic hepatitis C (HCV). This study was conducted to evaluate the effect of silymarin liver support as an adjunctive to local triamcinolone acetonide orabase in the treatment of atrophic/erosive oral lichen planus in hepatitis C positive patients.
\end{abstract}

Methods: Twenty HCV patients with erosive lichen planus were divided into two groups, 10 patients each: Group I was treated with topical triamicinolone acetonide in orabase, group II was treated with topical triamicinolone acetonide in orabase and systemic silymarin $140 \mathrm{mg}$ capsule 3 times daily for 3 months. Each patient was examined at baseline, 2, weeks and 1,2 and 4 months of therapy. Pain was scored using the visual analogue scale. Serum level of TNF-alpha (TNF- $\alpha$ ), AST and ALT were estimated at baseline 1,2 and 4 months' evaluation periods.

Results: Significant decrease in pain score was observed in both groups and there was a statistically significant difference between them at all treatment periods in favor to group II. Additionally, both groups showed a decrease in the size of lesions which was greater in group II compared to the control group. A significant reduction of the mean TNF- $\alpha$ continued up to 6 months in both groups with statistically insignificant difference between them at one month, while statistically significant difference in favor to group II at 2 and 4 months was observed.

Conclusion: The combination of topical triamicinlone and systemic silymarin could be suggested as a promising therapeutic alternative to systemic corticosteroid for hepatitis $\mathrm{C}$ virus associated oral lichen planus, and immunocompromised patients.

Key words: Hepatitis C Virus, Oral lichen planus, TNF- $\alpha$

\section{INTRODUCTION}

Oral lichen planus (OLP) is a chronic mucocutaneous disease with an immunological etiology. The exact etiology of OLP is still unknown, but it is mostly considered as a multifactorial process. It is well documented that the disease is a T-cell mediated autoimmune disease in which the cytotoxic CD8+ T cells trigger apoptosis of the basal cells of the oral epithelium. ${ }^{1}$

\footnotetext{
* Associate prof. Oral Medicine, Periodontology, Oral Diagnosis and Radiology Faculty of Dentistry, Tanta University, Egypt
} 
Lichenoid reaction is a condition mimicking OLP and can be differentiated by history only. It can be induced by drug, chemical, bacterial, post bone marrow transplantation and viral causes., ${ }^{2,3}$

Oral lichen planus was found to be associated with a number of viral infections including EpsteinBarr virus, Cytomegalovirus, Varicella zoster virus, human Herpes virus, human Papilloma virus, and human immunodeficiency virus. However, many epidemiological evidences strongly suggest that OLP is one of the most common extrahepatic manifestations of hepatitis $\mathrm{C}$ virus (HCV) infection ${ }^{4-6}$.

The pathogenic role of $\mathrm{HCV}$ in the development of OLP is still unclear. HCV could be a potential antigen presented by Langerhans cells, followed by activation and migration of lymphocytes resulting in damage to basal cells via cytokines of cytotoxic $\mathrm{T}$ cells ${ }^{7}$. Another point of view showed that, alteration of epithelial antigenicity at sites of mucocutaneous replication leading either to direct activation of cytotoxic $\mathrm{T}$ cells or to production of antibodies against epithelial antigens is caused by virus replication ${ }^{8-9}$.

Petruzzi et al. ${ }^{10}$, demonstrated differences in lymphocyte subpopulations between HCV positive oral LP patients and HCV negative patients with oral LP. Moreover, Carrozzo et al., ${ }^{11}$ have suggested that genetic polymorphism of interferon-gamma and tumor necrosis factor-alpha may contribute to the development of oral lichen planus.

Additionally, a strong believe that, this cellular reaction may be attributed to the local production of cytokines which in turn can stimulate the production of reactive oxygen species (ROS) causing oxidative damage to the tissues. ROS produced by keratinocytes, fibroblasts and various inflammatory cells could result in disequilibrium between the prooxidant and antioxidants leading to destruction and damage to cell membrane by lipid peroxidation ${ }^{12}$.

Medical management of oral lichen planus remains challenging. Systemic and topical corticosteroids are probably the most effective treatment modality for patients with erosive OLP. De- spite the therapeutic effects of corticosteroids, they have significant morbidity and disturbing adverse effects such as fungal infections and adrenal suppression. Moreover, steroid use is contraindicated in patients who are breastfeeding, diabetic and have to be used with caution in patients with viral hepatitis ${ }^{13}$.

Silymarin (Silybum marianum) is a unique flavonoid complex-containing silybin, silydianin, and silychirisin, that is derived from the milk thistle plant $^{14}$, many studies have been done on silymarin, they used it as a supportive treatment for inflammatory liver conditions such as cirrhosis, hepatitis, and other toxins-related conditions ${ }^{15}$. Silymarin is used to increase the survival rate of patients with cirrhosis ${ }^{16}$, complement the treatment of viral hepatitis, protect against industrial poisons, such as carbon tetrachloride ${ }^{17}$ and protect against pharmaceuticals that stress the liver, such as acetaminophen and tetracycline ${ }^{18}$.

As an antioxidant, silymarin scavenges the free radicals that can damage cells exposed to toxins. Silymarin is at least ten times more potent in antioxidant activity than vitamin $\mathrm{E}^{19-20}$. It increases the level of the important antioxidant such as glutathione in liver, superoxide dismutase and catalase ${ }^{22}{ }^{21}$. Glutathione is responsible for detoxifying a wide range of hormones, drugs, and chemicals. Moreover, it stimulates protein synthesis in the liver, which results in an increase in the production of new liver cells to replace the damaged ones ${ }^{23}$ and exerts membrane stabilization. Furthermore, it reduces the inflammatory reaction, inhibits the fibrosis of the liver, reduces tumor cell proliferation and suppresses tumor necrosis factor $-\alpha(\mathrm{TNF}-\alpha)^{15}$.

Since free radicals and ROS play important roles in both OLP pathogenesis and carcinogenesis ${ }^{24}$, hence, the present study was designed to compare the adjunctive antioxidative effect of systemic silymarin $140 \mathrm{mg}$ tds with local cortisone formula versus local cortisone alone, in the management of OLP in patients with hepatitis $\mathrm{C}$ virus infection. 


\section{SUBJECTS AND METHODS}

Twenty patients with clinically and/or histopathologically confirmed erosive OLP who were positive for HCV antibody (anti-HCV) and HCV RNA were selected from the Department of Oral Medicine, Faculty of Dentistry, Tanta University.

\section{Ethical considerations}

Ethical committee of Tanta University, Faculty of Dentistry approval was obtained before the trial started and all patients gave written informed consent.

\section{Inclusion criteria}

1. Patients with clinical diagnosis of erosive OLP (presence of painful bilateral atrophic-erosive oral lesions, mostly symmetrical lesions, and presence of a lace-like network of slightly raised white lines)

2. Age between 30 and 70 years

3. Patients who were positive for $\mathrm{HCV}$, determined by second generation anti-HCV assay and serum HCV RNA by the reverse transcription polymerase chain reaction (RT-PCR) and did not receive any treatment for virus $\mathrm{C}$ or failed treatment with antiviral drugs

4. Patients who were negative for serum hepatitis B surface antigen (HBsAg).

5. Patients who were willing to be enrolled in this study and had the ability to complete the study.

\section{Exclusion criteria}

- Pregnancy

- Patient suffering from another autoimmune disease

- Smokers

- Patients with lichenoid reaction due to drug intake or other predisposing conditions
All patients had previously been treated by eliminating potential irritating factors, for example, bad fillings, rough edges, and calculus. However, the patients did not show clinical improvement and their condition seemed to be refractory to these treatments.

The patients were classified randomly into two treatment groups, 10 patients each, using sealed envelopes as follows:

Group I (control group) treated by topical application of thin layer of triamcinolone acetonide in ora-base (Kenalog in orabase: Bristol-Myers, Squibb, Spain) on sterile gauze after careful dryness to the site of application 4 times a day i.e. following each meal and at bed time for 3 months.

Group II (test group) treated with topical application of thin layer of triamcinolone acetonide in ora-base on sterile gauze after careful dryness to the site of application 4 times a day i.e. following each meal and at bed time in addition to systemic silymarin $140 \mathrm{mg}$ capsule 3 times daily for 3 months.

Each patient was examined at the beginning of treatment, and then after 2 weeks, 1, 2 and 4 months of therapy. Pain was scored using the visual analogue scale (VAS), a well-documented method of pain assessment ${ }^{25}$.

The severity of pain and pain sensation were evaluated according to the following scales:

Scale 0: no pain: $\mathrm{VAS}=0$.

Scale 1: mild pain: $0<\operatorname{VAS} £ 3.5$.

Scale 2: moderate pain: $3.5<\mathrm{VAS} £ 7$.

Scale 3: severe pain: $7<\mathrm{VAS} £ 10$.

Patients were asked to score their intensity of pain at each visit. Pain scores ranged from 0 (no pain) to 10 (extreme pain). The patients were asked to report immediately if there was any side-effect at any time during the study. Changes in clinical findings were recorded and documented with photographs every other week during the treatment period. 


\section{Estimation of the serum level of TNF-alpha:}

Three cc venous blood samples were collected from all patients before treatment and after 1,2 and 4 months from treatment and centrifuged at a rate of $3000 \mathrm{rpm}$ to separate the serum which was stored at $-70^{\circ} \mathrm{C}$ till analysis. TNF- $\alpha$ was estimated by Enzyme Linked Immunosorbent Assay (ELISA) using commercially available human TNF- $\alpha$ kits manufactured by Bender Medsystems CO. ELISA was performed according to manufacturer's instruction. The microtiter plate was read at $450 \mathrm{~nm}$. The sensitivity of TNF ELISA was $1.5 \mathrm{pg} / \mathrm{ml}$.

Serum alanine aminotransferase (ALT), and aspartate aminotransferase (AST) were estimated using a commercially available diagnostic kit (Agappe Diagnostics Pvt. Ltd, Ernakulam. Kerala) at baseline, 1,2, and 4 months evaluation periods

\section{Statistical analysis}

All the results were tabulated and statistically analyzed using SPSS software (version 20®; SPSS Inc., Chicago, Illinois, USA). Data were presented as means and SDs. The two study groups were compared using independent samples $t$-test. Moreover, within each group, paired sample $t$-test was used to determine significant changes between time points for parametric data. The significance level was set at $P$ value less than 0.05 .

\section{RESULTS}

Gender and age distribution of the patients (12 3 females and eightseven males) is shown in table 1 and the results of treatment are shown in table 2,3,4 and 5. The most frequent symptoms before treatment were burning sensation, pain and ulceration. The most frequent form of lesions was atrophic/erosive form. All patients finished the treatment protocol and showed either complete or partial response or recurrence of the lesion at 3-4 months of the study.

Results of the present study showed that, there was no significant differences at baseline evaluation periods between the two groups regarding the studied parameters $\mathrm{P}>0.05$.

The use of medications in the two groups led to statistically significant decrease in pain scores as indicated by VAS values $(\mathrm{P}<0.001)$ as compared to baseline values. The differences between the two groups were statistically significant at all treatment periods in favor to the combined treatment (table 2).

The use of a combination of topical triamcinolone acetonide in orabase and silymarin $140 \mathrm{mg}$ capsule (GII) and triamcinolone in orabase alone (GI) led to a decrease in the size of lesions. The decrease in the size of the lesions was greater in the test group compared to the control group fig $(1,2,3,4,5 \& 6)$.

Table (3) shows that, there was a statistically significant reduction of the mean serumTNF- $\alpha$ values that continued up to the end of the study with both treatment modalities. The mean difference of TNF- $\alpha$, between the two treatment groups was statistically insignificant at one month $\mathrm{P}=0.153$ while there was statistically significant difference between the two treatment modalities in favor to group II combined treatment at 2 and 4 months $(\mathrm{P}=0.000$, and 0.005$)$ respectively.

Table 4 and 5 showed the results of serum AST and ALT in the study and control group and the effect of both treatment modalities on them. The results showed that, the combined treatment with topical application of cortisone and systemic administration of silymarin resulted in statistically significant reduction in serum AST up to the end of the study as compared to the mean baseline value $\mathrm{P}<0.001$. Similarly, group II showed statistically significant reduction in ALT at one-month $\mathrm{P}<0.001$ followed by slight increase at 2 and 4 months but still below baseline and statistically significant reduction $(\mathrm{P}=$ 0.001 and 0.003 respectively) as compared to their baseline value. On the other hand, control group showed statistically insignificant reduction in both serum AST and ALT at all treatment evaluation periods. 
TABLE (1): Sex and age distribution in the study and control groups

\begin{tabular}{|c|c|c|}
\hline & GI & GII \\
\hline & Male $=4$ & Male $=3$ \\
Sex & Female $=6$ & Female $=7$ \\
\hline Age range & $30-68$ & $35-66$ \\
Average & 53.5 & 52.2 \\
\hline
\end{tabular}

TABLE (2): The effect of the treatment modalities on the VAS score at different evaluation periods

\begin{tabular}{|c|c|c|c|c|c|}
\hline $\begin{array}{c}\text { Groups } \\
\text { Time }\end{array}$ & \multicolumn{2}{|c|}{$\begin{array}{c}\text { Group I }(\mathrm{n}=10) \\
\text { mean } \pm \text { SD }\end{array}$} & \multicolumn{2}{c|}{$\begin{array}{c}\text { Group II }(\mathrm{n}=10) \\
\text { mean } \pm \text { SD }\end{array}$} & $\mathrm{P}$ \\
\hline Baseline & $7.00 \pm 0.81$ & & $6.9 \pm 1.1$ & $\mathrm{P}=0.82$ \\
\hline 2 weeks & $3.4 \pm 1.26$ & $\begin{array}{c}\mathrm{t}=5.82 \\
\mathrm{P}=0.000^{* * *}\end{array}$ & $\begin{array}{c}\mathrm{t}=12.34 \\
\mathrm{P}=0.000^{* * *}\end{array}$ & $\mathrm{P}=0.02^{*}$ \\
\hline One month & $2.6 \pm 0.84$ & $\begin{array}{c}\mathrm{t}=10.31 \\
\mathrm{P}=0.000^{* * *}\end{array}$ & $\begin{array}{c}\mathrm{t}=16.47 \\
\mathrm{P}=0.000^{* * *}\end{array}$ & $\mathrm{P}=0.01^{*}$ \\
\hline 2 months & $2.7 \pm 0.67$ & $\begin{array}{c}\mathrm{t}=0.167 \\
\mathrm{P}=0.000^{* * *}\end{array}$ & $0.90 \pm 0.74$ & $\begin{array}{c}\mathrm{t}=23.23 \\
\mathrm{P}=0.000^{* * *}\end{array}$ & $\mathrm{P}=0.000^{* * *}$ \\
\hline 4 months & $2.5 \pm 0.84$ & $\begin{array}{c}\mathrm{t}=16.74 \\
\mathrm{P}=0.000^{* * *}\end{array}$ & $\begin{array}{c}\mathrm{t}=11.83 \\
\mathrm{P}=0.000^{* * *}\end{array}$ & $\mathrm{P}=0.005^{* *}$ \\
\hline
\end{tabular}

TABLE (3): The effect of the different treatment modalities on serum TNF- $\alpha(\mathrm{pg} / \mathrm{ml})$ at different evaluation periods

\begin{tabular}{|c|c|c|c|c|c|}
\hline \multirow{2}{*}{ Groups } & \multicolumn{2}{|c|}{$\begin{array}{c}\text { Group I }(\mathrm{n}=10) \\
\text { mean } \pm \text { SD }\end{array}$} & \multicolumn{2}{c|}{$\begin{array}{c}\text { Group II }(\mathrm{n}=10) \\
\text { mean } \pm \text { SD }\end{array}$} & $\mathrm{P}$ \\
\hline Baseline & $16.54 \pm 0.46$ & & $16.40 \pm 0.60$ & $\mathrm{P}=0.06$ \\
\hline One month & $14.56 \pm 0.99$ & $\begin{array}{c}\mathrm{t}=5.07 \\
\mathrm{p}=0.001^{* * *}\end{array}$ & $13.50 \pm 1.42$ & $\begin{array}{c}\mathrm{t}=4.44 \\
\mathrm{P}=0.000^{* * *}\end{array}$ & $\mathrm{P}=0.153$ \\
\hline 2months & $13.65 \pm 0.88$ & $\begin{array}{c}\mathrm{t}=8.79 \\
\mathrm{p}=0.000^{* * *}\end{array}$ & $12.56 \pm 1.32$ & $\begin{array}{c}\mathrm{t}=7.57 \\
\mathrm{P}=0.000^{* * *}\end{array}$ & $\mathrm{P}=0.045^{*}$ \\
\hline 4 months & $12.93 \pm 0.89$ & $\begin{array}{c}\mathrm{t}=9.92 \\
\mathrm{p}=0.000^{* * *}\end{array}$ & $10.72 \pm 1.11$ & $\begin{array}{c}\mathrm{t}=12.88 \\
\mathrm{P}=0.000^{* * *}\end{array}$ & $\mathrm{P}=0.000^{* * *}$ \\
\hline
\end{tabular}

TABLE (4): The effect of the treatment modalities on the mean AST (IU/l) at the study evaluation periods.

\begin{tabular}{|c|c|c|c|c|c|}
\hline Time & \multicolumn{2}{|c|}{$\begin{array}{c}\text { Group I }(n=10) \\
\text { mean } \pm \text { SD }\end{array}$} & \multicolumn{2}{|c|}{$\begin{array}{c}\text { Group II }(\mathrm{n}=10) \\
\text { mean } \pm \mathrm{SD}\end{array}$} & $\mathrm{P}$ \\
\hline Baseline & $37 \pm 2.57$ & & $38.00 \pm 1.15$ & & $\begin{array}{c}\mathrm{T}=-1.088 \\
\mathrm{P}=0.292\end{array}$ \\
\hline 1 month & $35.8 \pm 3.52$ & $\begin{array}{l}\mathrm{t}=1.909 \\
\mathrm{P}=0.089\end{array}$ & $24.6 \pm 2.59$ & $\begin{array}{c}\mathrm{t}=12.8 \\
\mathrm{P}=0.000^{* * * *}\end{array}$ & $\begin{array}{c}\mathrm{T}=7.608 \\
\mathrm{P}=0.000 * * *\end{array}$ \\
\hline 2 months & $35.30 \pm 2.49$ & $\begin{array}{l}\mathrm{t}=10.31 \\
\mathrm{P}=0.118\end{array}$ & $23.00 \pm 1.82$ & $\begin{array}{c}\mathrm{t}=19.3 \\
\mathrm{P}=0.000^{* * *}\end{array}$ & $\begin{array}{c}\mathrm{T}=15.611 \\
\mathrm{P}=0.000 * * *\end{array}$ \\
\hline 4 months & $35.50 \pm 1.18$ & $\begin{array}{l}\mathrm{t}=2.193 \\
\mathrm{P}=0.056\end{array}$ & $23.2 \pm 2.25$ & $\begin{array}{c}\mathrm{t}=17.07 \\
\mathrm{P}=0.000^{* * *}\end{array}$ & $\begin{array}{c}\mathrm{T}=14.58 \\
\mathrm{P}=0.000 * * *\end{array}$ \\
\hline
\end{tabular}


TABLE (5): The effect of the treatment modalities on the mean ALT (IU/l) at the study evaluation periods.

\begin{tabular}{|c|c|c|c|c|c|}
\hline $\begin{array}{l}\text { Groups } \\
\text { Time }\end{array}$ & \multicolumn{2}{|c|}{$\begin{array}{c}\text { Group I }(\mathrm{n}=10) \\
\text { mean } \pm \text { SD }\end{array}$} & \multicolumn{2}{|c|}{$\begin{array}{c}\text { Group II }(\mathrm{n}=10) \\
\text { mean } \pm \text { SD }\end{array}$} & $P$ \\
\hline Baseline & $29.6 \pm 3.20$ & & $31.9 \pm 3.95$ & & $\begin{array}{c}\mathrm{T}=-1.378 \\
\mathrm{P}=0.186\end{array}$ \\
\hline 1 month & $30.8 \pm 3.48$ & $\begin{array}{l}t=-1.164 \\
P=0.274\end{array}$ & $23.4 \pm 2.41$ & $\begin{array}{c}\mathrm{t}=4.83 \\
\mathrm{P}=0.000^{* * * *}\end{array}$ & $\begin{array}{c}\mathrm{T}=5.419 \\
\mathrm{P}=0.000 * * *\end{array}$ \\
\hline 2 months & $30,20 \pm 1.39$ & $\begin{array}{l}\mathrm{t}=-0.452 \\
\mathrm{P}=0.662\end{array}$ & $25.30 \pm 1.88$ & $\begin{array}{c}\mathrm{t}=4.038 \\
\mathrm{P}=0.001^{* *}\end{array}$ & $\begin{array}{c}\mathrm{T}=6.268 \\
\mathrm{P}=0.000 * * *\end{array}$ \\
\hline 4 months & $29 . .30 \pm 2.62$ & $\begin{array}{c}\mathrm{t}=0.237 \\
\mathrm{P}=0 . .818\end{array}$ & $26.00 \pm 1.76$ & $\begin{array}{c}\mathrm{t}=4.49 \\
\mathrm{P}=0.003 * *\end{array}$ & $\begin{array}{c}\mathrm{T}=3.055 \\
\mathrm{P}=0.007 * *\end{array}$ \\
\hline
\end{tabular}

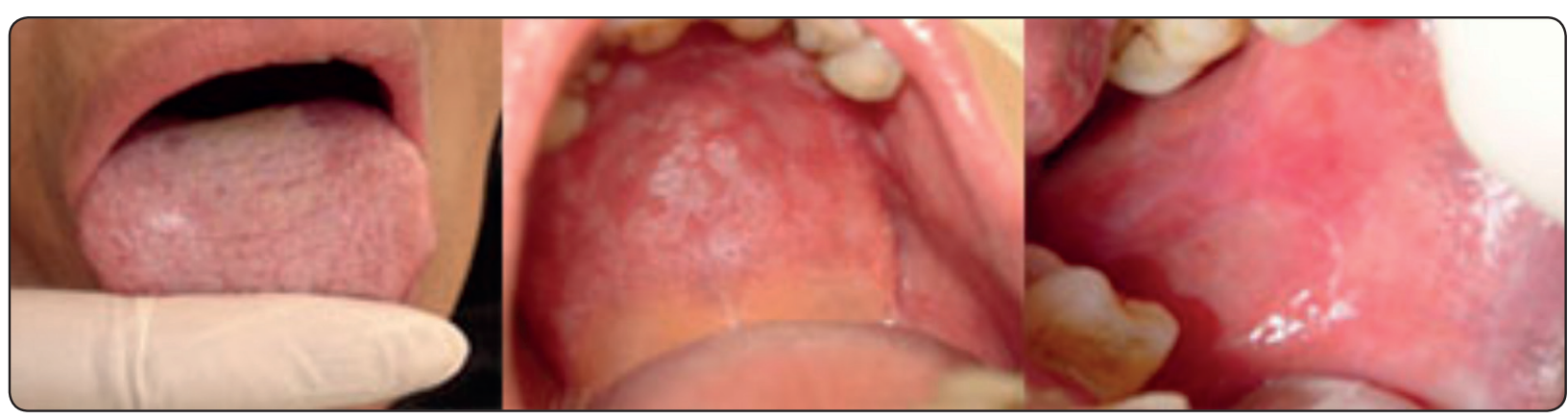

Fig. (1): Tongue, palate and cheek lesions of oral lichen planus in $\mathrm{HCV}+\mathrm{ve}$ patient (group II)before treatment

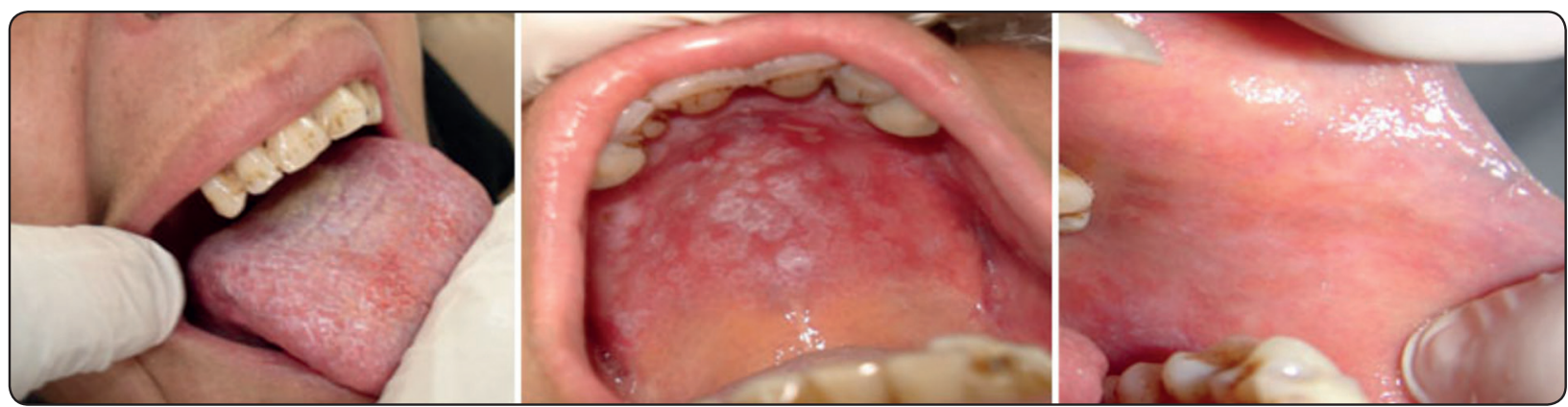

Fig. (2): Tongue, palate and cheek lesions of oral lichen planus in HCV +ve patient 2 months after treatment with topical triamcinolone acetonide in orabase plus systemic administration of silymarin $140 \mathrm{mg}$ capsule 3 times daily for 3 months

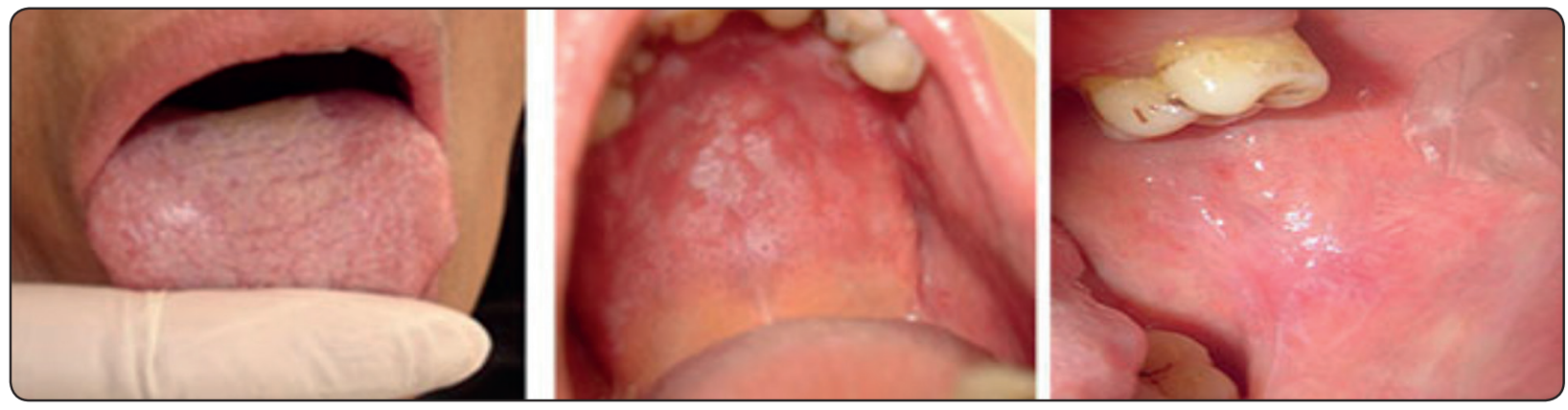

Fig. (3): Tongue, palate and cheek lesions of oral lichen planus in HCV +ve patient 4 months after treatment with topical triamcinolone acetonide in orabase plus systemic administration silymarin $140 \mathrm{mg}$ capsule 3 times daily for 3 months (same patient shown in figs 1 \& 2) 


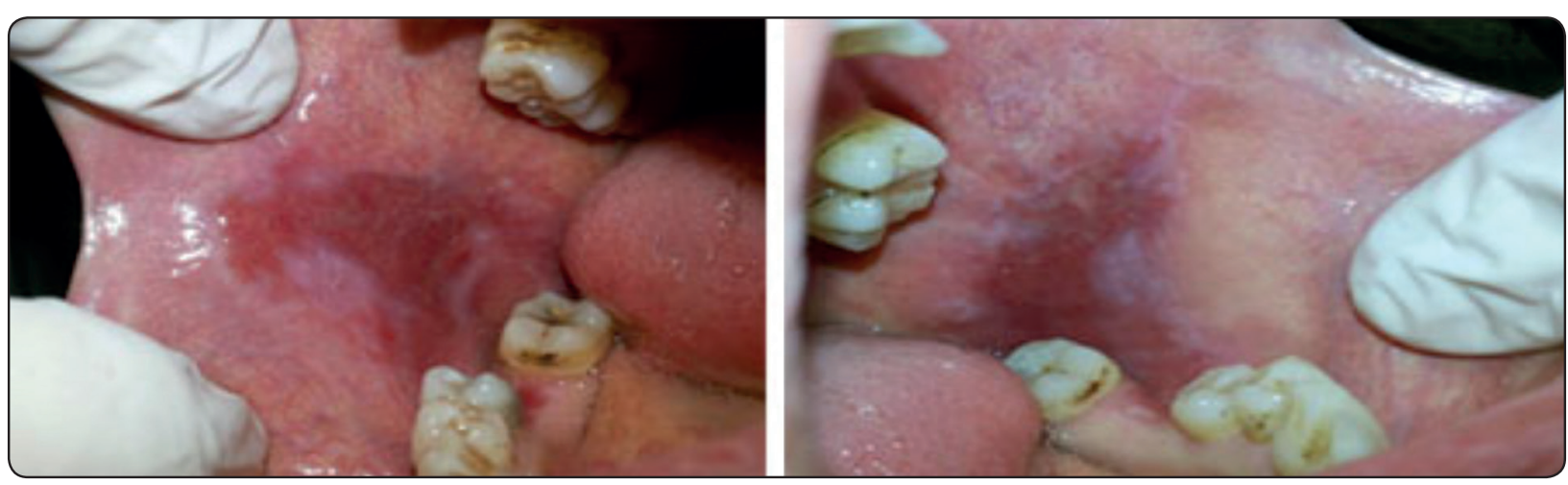

Fig. (4) : Bilateral cheek lesions of oral lichen planus in HCV +ve patient before treatment (group I)

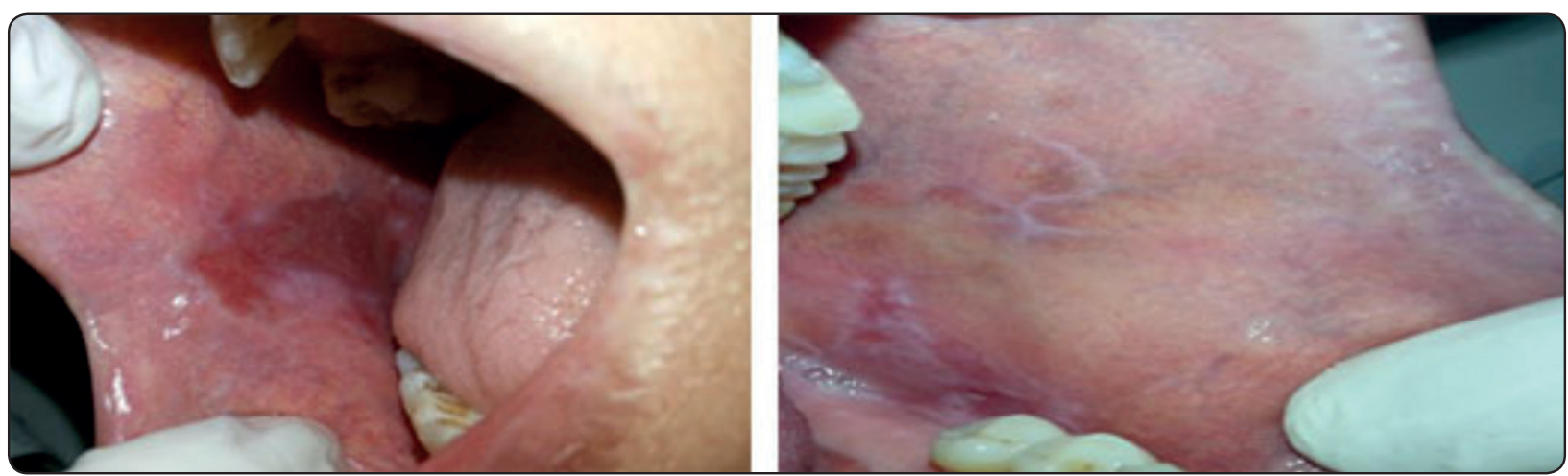

Fig. (5): Bilateral cheek lesions of oral lichen planus in $\mathrm{HCV}$ +ve patient 4 months after treatment with topical triamcinolone acetonide in orabase alone 4 times a day for 3 months

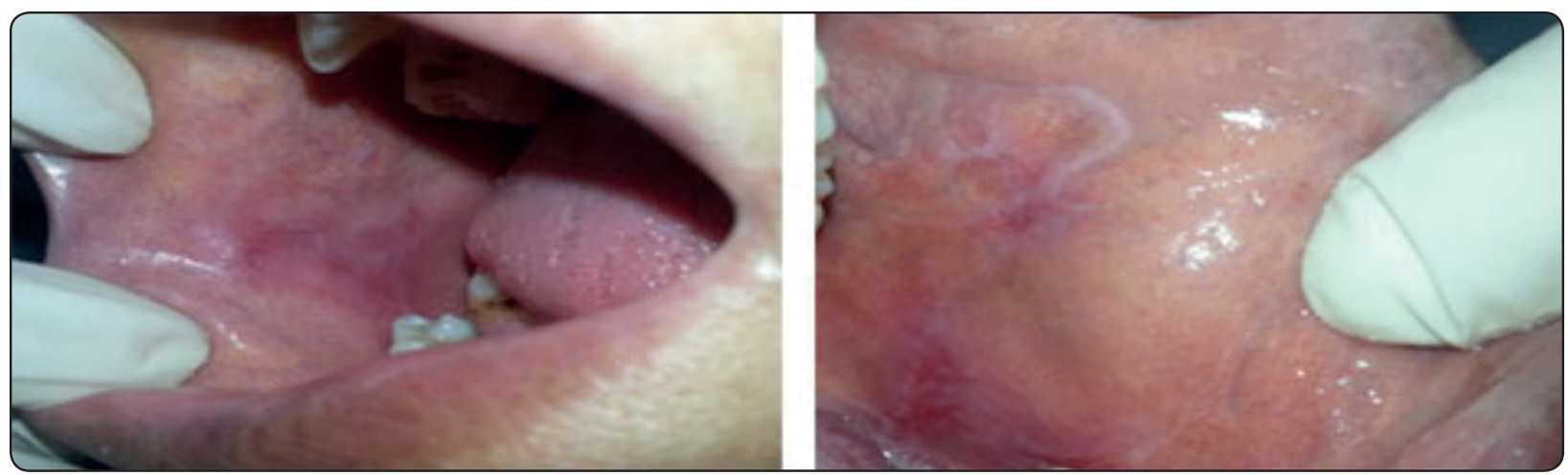

Fig. (6): Bilateral cheek lesions of oral lichen planus in HCV +ve patient 4 months after treatment with topical triamcinolone acetonide in orabase alone 4 times a day for 3 months 


\section{DISCUSSION}

In recent years, the relation between OLP and liver diseases have been reported in many investigations and it was reported that OLP is frequently associated with $\mathrm{HCV}$ infection ${ }^{26,27}$. $\mathrm{HCV}$ infection is associated with immunological disorders and extrahepatic manifestations as membra no proliferative glomerulonephritis, rheumatoid arthritis, autoimmune thyroiditis and Sjogren syndrome ${ }^{4}$.

Meta-analysis by Shengyuan et al., ${ }^{27}$ revealed an important association between HCV and OLP. However, the presence of HCV -RNA in epithelial cells in oral tissues from OLP lesions may suggest $\mathrm{HCV}$ action. Additionally, Carrazo et al., ${ }^{28}$ observed that, there was a higher frequency of HLA class II allele HLA-DR6 in OLP patients with HCV infection in comparison to those without $\mathrm{HCV}$ infection, which also explains the geographical heterogeneity of the association between HCV and OLP.

It is worthy to be noted that, OLP in patients with $\mathrm{HCV}$ infection were more likely to be erosive, when compared to non-infected OLP patients ${ }^{29-31}$. This may reflect the link between the two conditions.

Nagao et al., ${ }^{32}$ reported that, the disappearance of HCV-RNA and improvements in liver function over a period of $>3$ years appears to resolve OLP lesions thus, the elimination of HCV inhibits the onset of various extrahepatic manifestations.

$\mathrm{HCV}$ acts locally, altering the function of the epithelial cells, or the immune response of the host to HCV is responsible for the development of OLP. Thus, host factors rather than geographic factors may be more important in the pathogenesis of HCVrelated OLP $^{33}$.

Treatment of OLP generally includes systemic administration of steroids, or topical application of steroids, but the effects of these drugs are limited. Steroids use is contraindicated in diabetes mellitus patients and used with caution in patients with hepatic diseases, glaucoma, pregnancy, HIV infection, tuberculosis, candidiasis, and hypertension ${ }^{34}$. In the present study Silymarin was used which is a unique flavonoid complex containing silybin, silydianin, and silychrisin that is derived from the milk thistle plant, it is best known for its use as a liver protectant and decongestant ${ }^{35}$. Hundreds of studies have been done on silymarin, and it is approved in the German Commission E Monographs as a supportive treatment for inflammatory liver conditions such as cirrhosis, hepatitis, and fatty infiltration caused by alcohol and other toxins ${ }^{17,36}$.

In general, the results of the present study showed a significant intergroup improvement of pain sensation and reduction of lesion size favoring Group II over Groups I, where there was a statistically significant improvement in pain score (VAS) in both treatment groups along the study periods. In relation to group I this could be explained by the anti-inflammatory action of corticosteroid through synthesis of lipocortin-1 which inhibits phospholipase A2 so decrease arachidonic acid and decrease synthesis of prostaglandins, decrease capillary permeability and inflammatory edema. Moreover, corticosteroids suppress T cell migration and decrease antibody antigen reaction thus lead to decrease surface erythema and decrease pain as it inhibits the synthesis of leukotrienes (mediators of inflammation).

On the other hand, the effectiveness of silymarin was suggested by the improvements in clinical findings in group II (silymarin treated group) that showed excellent pain relief in all treated cases. Results showed significant differences between group II and group I at all evaluation periods in favor to group II which may be explained by the synergistic effect of silymarin to topical cortisone. Silymarin has been reported to have antioxidant, free radical scavengers raising the cellular content of glutathione that lead to the lipid peroxidation inhibition, increasing membrane stability leading 
to enhancement of wound healing ${ }^{37}$. Additionally, it has the capacity to regulate nuclear expression by means of a steroid-like effect, (attributed to a structural similarity of silymarin to steroid hormones) followed by tissue regeneration ${ }^{38}$. Moreover, it suppresses function of T-lymphocyte and stimulates the inflammatory pathways at higher $\operatorname{doses}^{39}$.

Yamamoto et $\mathrm{al}^{40}$ and Sklavounou et $\mathrm{al}^{41}$ reported high serum levels of TNF- $\alpha$ in all patients with OLP with other proinflammatory cytokines, hence TNF- $\alpha$ in serum was used as a marker for the treatment of OLP in this study as it is released from oral mucosal mast cells causing up-regulation of endothelial leucocyte adhesion molecules expression which induces $\mathrm{T}$ lymphocyte migration from peripheral blood to the developing lesion ${ }^{42}$. Additionally, free radical is an important transcription factor for inflammatory cytokines genes including IL-2 and TNF- $\alpha$. It was quantified using ELISA which is known to be sensitive, reliable, simple and widely used and very little sample is required for estimation ${ }^{43}$.

The present study showed that serum TNF- $\alpha$ was decreased and continued up to the end of the study in both treatment modalities with statistically significant difference between the two treatment modalities in favor to group II combined treatment at 2 and 4 months $\mathrm{P}=0.000$, and 0.005 respectively. This can be explained by the well-documented anti-inflammatory properties of Silymarin. It inhibits neutrophil migration, stabilizes mast cells and affects the synthesis of prostaglandins and leukotrienes ${ }^{43}$. In some studies, it has been reported that silymarin is also an immunomodulatory agent, increasing IFN- $\gamma$ IL-4 and IL10, but decreasing the T-cell production of TNF- $\alpha^{38}$.

Both treatment modalities resulted in reduction of the size of the lesion especially the combined treatment of topical cortisone and systemic silymarin, this can be explained by the antioxidant properties of silymarin since the overproduction of reactive oxygen species (ROS) results in oxidative stress thereby causing cytotoxicity and delayed wound healing. Therefore, elimination of ROS could be an important strategy in healing of chronic wounds ${ }^{44}$.

In conclusion, patients with $\mathrm{HCV}$ should undergo periodic oral examination, and patients with OLP should undergo screening tests for HCV infection. Because chronic hepatitis $\mathrm{C}$ is an asymptomatic disease, which in many cases leads to severe consequences, the knowledge of its extrahepatic manifestations may help identify asymptomatic patients infected with $\mathrm{HCV}$.

Systemic silymarin is an effective adjunctive supplement to topical cortisone in the treatment of oral lichen planus lesions. The combination of topical triamcinolone and silymarin capsules could be suggested as a promising therapeutic alternative to systemic cortisone for hepatitis $\mathrm{C}$ virus associated OLP, and immunocompromised patients. Therefore, further studies may be recommended using a larger sample size and a longer evaluation period, especially after the discontinuation of the medication.

Conflict of Interest: No conflict of interest.

Financial Disclosure: This study received no financial support.

\section{REFERENCES}

1- Scully C, El-Kom M. Lichen planus: review and update on pathogenesis. J Oral Pathol. 1985;14:431-458.

2- Habif TP. Lichen planus. In: Habif TP, editor. Clinical dermatology: a colour guide to diagnosis and therapy. 4 th ed. Chile: Mosby Inc.; 2004. pp. 250-256.

3- Kurokawa $\mathbf{M}^{1}$, Hidaka T, Sasaki H, Nishikata I, Morishita K, Setoyama M. Analysis of hepatitis C virus RNA in the lesions of lichen planus in patient with chronic hepatitis $\mathrm{C}$ : detection of antigenomic as well as genomic strand $\mathrm{HCV}$ RNAs in lichen planus lesions. J Dermatol Sci. 2003; 32(1): 65-70. 
4- Asaad T, Samdani AJ. Association of lichen planus with chronic hepatitis C virus infection. Ann Saudi Med. 2005; 25:243-246.

5- Nagao Y, Sata M, Tanikawa K, Itoh K, Kameyama T. Lichen planus and hepatitis $\mathrm{C}$ virus in the Northern Kyushu region of Japan. Eur JClin Invest.1995; 25: 910-914.

6- Ingafou M, Porter SR, Scully C, Teo CG. No evidence of $\mathrm{HCV}$ infection or liver disease in British patients with oral lichen planus. Int J Oral Maxillofac Surg 1998; 27: 65-66.

7- Carrozzo M, Gandolfo S, Carbone M, Colombatto P, Broccoletti R, Garzino-Demo P, et al: Hepatitis C virus infection in Italian patients with oral lichen planus: a prospective case-control study. J Oral Pathol Med 1996, 25:527-533.

8- Tucker SC, Coulson IH: Lichen planus is not associated with hepatitis $\mathrm{C}$ virus infection in patients from North West England. Acta Derm Venereol 1999, 79:378-9.

9- Nagao Y, Kameyama T, Sata M: Hepatitis C virus RNA detection in oral lichen planus tissue. Acta Derm Venereol 1998, 78:355-357.

10- Petruzzi M, De Bebedittis M, Loria MP, Dambra P, D'Oronzio L, Capuzzimati C, et al: Immune response in patients with oral lichen planus and HC infection. Int $J$ Immunopathol Pharmacol 2004, 17:93-98.

11- Carrozzo M, Uboldi de Capai M, Dametto E, Fasano ME, Arduino P, Broccoletti R, et al: Tumor necrosis factoralpha and interferon-gamma polymorphisms contribute to susceptibility to oral lichen planus. J Invest Dermatol 2004, 122:87-94.

12- Sertan E, Sule CT, Warnakulasuriya S, Sevda O, Ayse EO, Duygu O, Yegane G. Evaluation of oxidative stress and antioxidant profile in patients with oral Lichen planus. J. Oral Pathol. Med., 2011,40:. 286-293

13- Miles DA, Howard MM. Diagnosis and management of oral lichen planus. Dermatol Clin. 1996;14:281-290.

14- Comelli MC, Mengs U, Prosdocimi M, Schneider C. Toward the definition of the mechanism of action of silymarin: Activities related to cellular protection from toxic damage induced by chemotherapy. Integr. Cancer Ther. 2007;6:120-129.

15- Mayer KE, Mayer RP, Lee SS. Silymarin treatment of viral hepatitis: a systematic review. J Viral Hepatitis. 2005;12:559-567.
16- Katiyar SK, Roy AM, Baliga MS. Silymarin induces apoptosis primarily through a p53-dependent pathway involving $\mathrm{Bcl}-2 / \mathrm{Bax}$, cytochrome $\mathrm{c}$ release, and caspase activation. Mol Cancer Ther. 2005;4:207-216.

17- Ferenci P, Dragosics B, Dittrich H, Frank H, Benda L, Lochs H, et al. Randomized, controlled trial of silymarin treatment in patients with cirrhosis of the liver. J Hepatol 1989;9:105-113.

18- Polyak SJ, Morishima C, Lohmann V, Pal S, Lee DY, Liu $\mathrm{Y}$, et al. Identification of hepatoprotective flavonolignans from silymarin. Proc Natl Acad Sci USA. 2010; 107: 5995-5999

19- Fu H, Lin M, Muroya Y, Hata K, Katsumura Y, Yokoya A, et al. Free radical scavenging reactions and antioxidant activities of silybin: Mechanistic aspects and pulse radiolytic studies. Free Radic. Res. 2009; 43:887-897.

20- Yin F, Liu J, Ji X, Wang Y, Zidichouski J, Zhang J. Silibinin: A novel inhibitor of $A \beta$ aggregation. Neurochem. Int. $2011 ; 58: 399-403$.

21- Domitrović R, Jakovac H, Marchesi VV, Blažeković B. Resolution of liver fibrosis by isoquinoline alkaloid berberine in $\mathrm{CCl}_{4}$-intoxicated mice is mediated by suppression of oxidative stress and upregulation of MMP2 expression. J. Med. Food. 2013; 16:518-528.

22- Köksal E, Gülçin I, Beyza S, Sarikaya O, Bursal E. In vitro antioxidant activity of silymarin. J. Enzyme Inhib. Med. Chem. 2009;24: 395-405.

23- Asghar Z, Masood Z. Evaluation of antioxidant properties of silymarin and its potential to inhibit peroxyl radicals in vitro. Pak. J. Pharm. Sci. 2008;21: 249-254.

24- Ergun S, Troşala, S C, Warnakulasuriya S, Özel S, Önal AE, Ofluoğlu D. Evaluation of oxidative stress and antioxidant profile in patients with oral Lichen planus. J. Oral Pathol. Med. 2011; 40 :286-293.

25- Mekorn L, Sererat T Taweesap W. Relative efficacy of fluocinolone acetonide compared with triamcinolone acetonide in treatment of oral lichen planus. J Oral Pathol Med. 1992; 21:456-458

26- Bagán J, Aguirre J, del Olmo J, Milián A, Peñarrocha M, Rodrigo J, et al. Oral lichen planus and chronic liver disease: a clinical and morphometric study of the oral lesions in relation to transaminase elevation. Oral Surg Oral Med, Oral Pathol. 1994;78: 337-342.

27-Shengyuan L, Songpo Y, Wen W, WenjingT, Haitao Z, BinyouW. Hepatitis $\mathrm{C}$ virus and lichen planus: a reciprocal 
association determined by meta-analysis. Arc Dermatol. 2009; 145: 1040-1047.

28- Carrozzo M, Brancatello F, Dametto E, Arduino P, Pentenero M, Rendine S, et al. Hepatitis C virus-associated oral lichen planus: is the geographical heterogeneity related to HLA-DR6? J Oral Pathol Med. 2005, 34:204208.

29- Ali AA, Suresh CS. Oral lichen planus in relation to transaminase levels and hepatitis C virus. J Oral Pathol Med. 2007;36: 604-608.

30- Gimenez-Garcia R, Perez-Castrillón JL. Lichen planus and hepatitis C virus infection. J Eur Acad Dermatol Venereol. 2003; 17: 291-295.

31- Dupond AS, Lacour JP, Lafont C, Ortonne JP. Prevalence of hepatitis $C$ virus in oral erosive lichen. Ann Dermatol Venereol. 1998;125: 676-678.

32- Nagao Y, Sata M, Suzuki H, Kameyama T, Ueno T, et al. Histological improvement of oral lichen planus in patients with chronic hepatitis $\mathrm{C}$ treated with interferon. Gastroenterology 1999; 117: 283-284.

33- Roy KM, Bagg J. Hepatitis C virus and oral disease: a critical review. Oral Dis. 1999; 5:270-277.

34- Sharma S, Saimbi CS, Koirala B. Erosive oral lichen planus and its management: a case series. J Nepal Med Assoc. 2008; 47:86-90.

35- Wagner H, Hörhammer L, Münster R. "The Chemistry of Silymarin (Silybin), the Active Principle of the Fruits of Silybum marianum." Arzneim-Forsch Drug Res. 1968; 18:688-696.

36- Comoglio A, Tomasi A, Malandrino S, Poli G, Albano E. Scavenging effect of silipide, a new silybin-phospholipid complex, on ethanol-derived free radicals, Biochem Pharmacol. 1995;50: 1313-1316.

37- Basiglio CL, Sanchez Pozzi EJ, Mottino AD, Roma MG. Differential effects of silymarin and its active component silibinin on plasma membrane stability and hepatocellular lysis. Chem Biol Interact. 2009;179: 297-303.

38- Saller R, Melzer J, Reichling J, Brignoli R, Meier R. An updated systematic review of the pharmacology of silymarin. Forsch Komp Klas Nat. 2007; 14:70-80.

39- Machicao F, Sonnenbichler J. Mechanism of the stimulation of RNA synthesis in rat liver nuclei by silybin. HoppeSeyler's Zeitschrift fur physiologische Chemie. 1977;358: 141-147.

40- Yamamoto T, Yoneda K, Ueta E, Osaki T. Serum cytokines, interleukin-2 receptor, and soluble intercellular adhesion molecule-1 in oral disorders. Oral Surgery, Oral Medicine, Oral Pathology. 1994;78: 727-735.

41- Sklavounou-Andrikopoulou A, Chrysomali E, Iakovou M, Garinis GA, Karameris A. Elevated serum levels of the apoptosis related molecules TNF- $\alpha$, Fas/Apo-1 and Bcl-2 in oral lichen planus. Journal of Oral Pathology and Medicine. 2004;33: 386-390

42- Manna SK, Mukhopadhyay A, Van NT, Aggarwal BB. Silymarin suppresses TNF-induced activation of NF-kappa B, c-Jun N-terminal kinase, and apoptosis. J. Immunol. 1999; 163:6800-6809.

43-Amsen D, de Visser KE, Town T. Approaches to Determine Expression of Inflammatory Cytokines. Methods Mol Biol. 2009; 511:107-142.

44- Dissemond J, Goos M, Wagner SN. The role of oxidative stress in the pathogenesis and therapy of chronic wounds. Hautarzt. 2002;53:718-723 